\title{
Theatre Survey
}

The Journal of the American Society for Theatre Research

Vol. 36, no. 1

May 1995

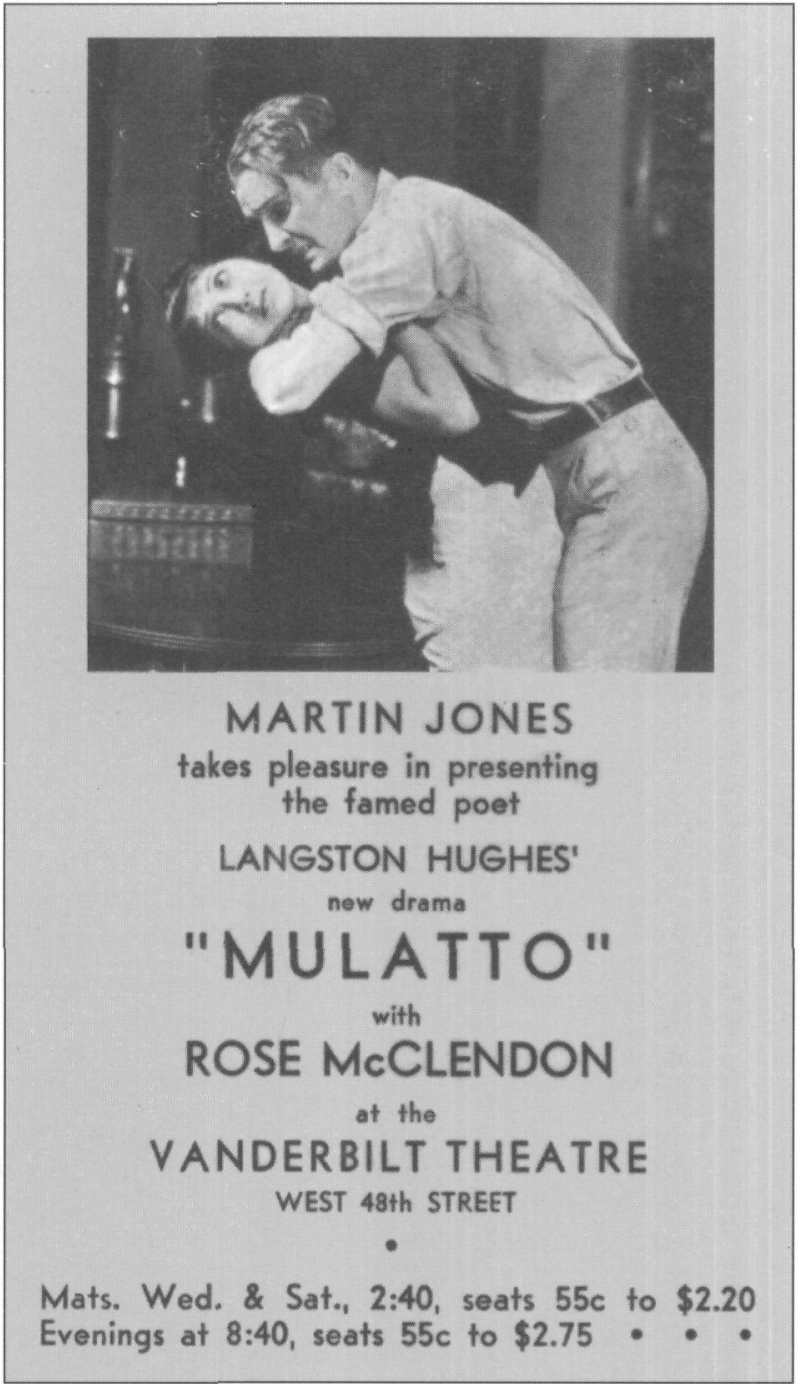




\title{
THEATRE SURVEY \\ The Journal of the American Society for Theatre Research
}

\author{
Editor \\ Barry Witham \\ Book Review Editor \\ J. Ellen Gainor \\ Editorial Assistant \\ Tonia Steed \\ Editorial Board
}

Tracy C. Davis (1996); Marvin Carlson (1997);

Thomas Postlewait (1995); Albert Wertheim (1996)

Articles submitted to Theatre Survey should be addressed to:

Gary J. Williams, Theatre Survey. Dept. of Drama, Catholic University of America, Washington, D.C. 20064.

Correspondence concerning book reviews should be addressed to:

J. Ellen Gainor, Cornell University, Department of Theatre Arts, Center for Theatre Arts, 430 College Avenue, Ithaca, NY 14850-4696.

Review assignments must be coordinated with the book review editor.

Correspondence concerning membership in the American Society for Theatre Research should be addressed to:

ASTR Records, Theatre Arts, P.O. Box 1897, Brown University, Providence, RI 02912.

Copyright 1995 by the American Society for Theatre Research, Inc.

\section{Editorial Policy and Practices}

Theatre Survey is chartered by the American Society for Theatre Research as a theatre history journal. This historical orientation, broadly conceived, includes most performance-centered studies, regardless of culture or critical methodology, as well as historiographic studies. Studies of dramatic literature are generally outside the purview of the journal, unless they contain references to actual performance.

Articles submitted are subject to juried review by members of the Society, which takes approximately three months. Manuscripts usually run between 15 and 50 pages, and should be prepared according to the Chicago Manual of Style. Submissions on disc, preferably Word Perfect or Microsoft Word, are welcome, as are illustrations. SASE required for return of manuscript. 


\section{THEATRE SURVEY}

\section{The Journal of}

\section{The American Society for Theatre Research}

Volume 36, No. 1

May 1995

CONTENTS

Editorial Note

Articles

Jay Plum

Accounting for the Audience in Historical Reconstruction:

Martin Jones's Production of Langston Hughes's Mulatto

Erika Fischer Lichte

What Are the Rules of the Game?

Some Remarks on The Yellow Jacket

Kevin J. Gardner

Theatrum Belli:

Late Restoration Comedy and the Rise of the Standing Army

Cheryl Black

Technique and Tact:

Nina Moise Directs the Provincetown Players

Special Section: Prague School Semiotics

Jan Mukařovský

On the Artistic Situation of Contemporary Czech Theatre (1945)

\section{Zdenèk Hořinek}

The Possibilities of Theatrical Montage

(Successive and Simultaneous)

Jiří Veltruský

Semiotics and Avant-garde Theatre

Michael L. Quinn

Uncertain Slovakia: Blaho Uhlár, Stoka and Vres

\section{Book Reviews}

PeterThompson and Glendyr Sacks, eds.,

The Cambridge Companion to Brecht

Reviewed by David Bathrick 
F.W. J. Hemmings, The Theatre Industry in Nineteenth-Century France F.W. J. Hemmings, Theatre and State in France, 1760-1905

Reviewed by Jeffrey S. Ravel

Sally Banes, Greenwich Village 1963: Avant-garde Performance and the Effervescent Body

Reviewed by Scott T. Cummings

Joel H. Kaplan and Sheila Stowell,

Theatre and Fashion: Oscar Wilde to the Suffragettes

Reviewed by Cary M. Mazer

Jane Kathleen Curry, Nineteenth-Century American Women Theatre

Managers

Reviewed by Rosemarie K. Bank

Faye E. Dudden,

Women in the American Theatre: Actresses and Audiences, 1790-1870

Reviewed by Kim Marra

Susan Melrose, A Semiotics of the Dramatic Text

Reviewed by Kornelia Tancheva

Ellen Donkin and Susan Clement, eds.

Upstaging Big Daddy: Directing Theater as if Gender and Race Matter Reviewed by Susan L. Chast

Samuel A. Hay, African American Theatre: An Historical and

Critical Analysis

Reviewed by Christine R. Gray

Meredith Anne Skura, Shakespeare the Actor and the Purposes

of Playing

Reviewed by Marguerite A. Tassi

Jurgen C. Wolter, ed. and comp.,

The Dawning of American Drama: American Dramatic Criticism, 1746-1915

Reviewed by Thomas F. Connolly

Rena Fraden, Blueprints for a Black Federal Theatre, 1935-1939

Reviewed by Glenda E. Gill

Ralph Willingham, Science Fiction and the Theatre

Reviewed by Rhona Justice-Malloy

Thomas S. Hischak, Stage It with Music:

An Encyclopedic Guide to the American MusicalTheatre

Dennis McGovern and Deborah Grace Winer, Sing Out, Louise!

150 Stars of the Musical Theatre Remember 50 Years on Broadway

Reviewed by Abigail Feder

Books Received

Cover: Plum: Poster for Martin Jones's production of Langston Hughes's Mulatto (1935). Courtesy of the Performing Arts Research Center, New York Public Library at Lincoln Center. 